\title{
Character Education of the Most Developed Countries in ASEAN
}

\section{Istiningsih ${ }^{1}$}

${ }^{1}$ Faculty of Education, State Islamic University Sunan Kalijaga Yogyakarta, Indonesia

\begin{abstract}
Character education into an international issue, especially in developing countries. More specifically in Indonesia, character education is a major issue in the 2012's to the present. What kind of education that may build character? To be able to answer this question, we need a broad and deep research. Research simpler related to character education is research aimed at finding supporting pillars of character education. So that the findings of this study can be implemented, then education is used as a model for education in Indonesia is among countries in ASEAN, with the hope of socio-cultural conditions there are similarities. So it is assumed that education happens to be in the same context. The results showed that Singapore as the most advanced countries in ASEAN from the perspective of economic, social, education, and technology. Therefore, education in Singapore is assumed better.The basic assumption is that there is a positive correlation between education and socio-culture. While socio-culture related to technology, economic and so on. The relationship is reciprocal. Character of Singapore society appointed as a result of education in Singapore. There are six kinds of characters which stand out in Singapore society. The theoritical research is aimed at finding hypothesis. Hypothetical model were found as follows: "There are thirteen pillars supporting character education".
\end{abstract}

Keywords: Character, Education, Developed country.

\section{Contents}

1. Introduction . .33

2. The Most Developed Country inASEAN

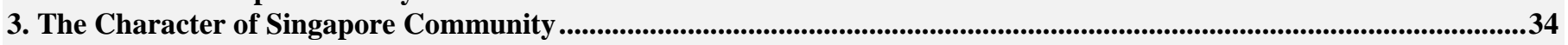

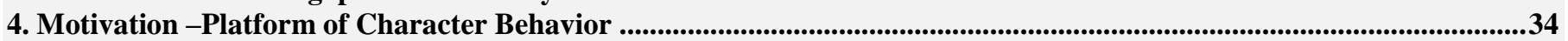

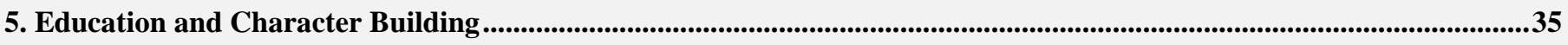

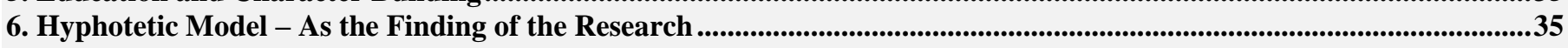

7. Conclusion.................................................................................................................................................................................................36

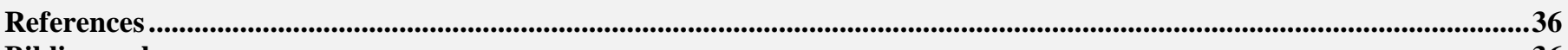

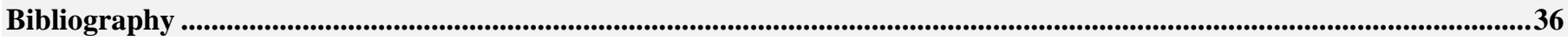

Citation | Istiningsih (2016). Character Education of the Most Developed Countries in ASEAN. Journal of Education and eLearning Research, 3(1): 32-37.

DOI: $10.20448 /$ journal.509/2016.3.1/509.1.32.37

ISSN | 2410-9991

\section{(c)) EY}

This work is licensed under a Creative Commons Attribution 3.0 License

Asian Online Journal Publishing Group 


\section{Introduction}

Character education is an education that is able to build character. ${ }^{1}$ Issues character occurred in several countries of the world, especially developing countries. Indonesia as a developing country vulnerable to the character. Government's concern about the character of the Indonesian nation, shown by the government with a policy issued by the character education. When talking about the characters, of course, can not be separated from education. Like two sides of a coin that is not separated from one another. National character is the result of education that occurs in a system of government.

Education is a condition which can alter a person's values and can influence the changes in a person's behaviors.Any environment can become a child's condition (family situation, TV programs, Understanding education is actually more comprehensive learning process.neighbors' appearance, street condition, society condition, school condition, etc.). A child's condition happens spontaneously, without a curriculum. Therefore, if the condition is favorable, it will become an disadvantage a child's education, if the condition is unfavorable, it will become a disadvantage for the child's development. ${ }^{2}$

Based on the definitionabove, it is actually a person's character is built from a variety of environments. This study does not separate and does not raise the issue of the educational environment which is responsible in building character. Based on the results of the study entitled "Contribution of Religion and Media in Building a Character of Students" stated that all environments such as self, family, school, community, life history, geography, political system, global system contributed to the character of the individual.

The study also would not design a model of education that can form the basis for planting the pillars of character education. Actually, it is important to find a model of education that can be the basis of the founding pillars of character education. This study would find pillars of education that could build person's character. And further characters in the research is limited for developed country's character most advanced country in Asean. Therefore, this study will also define the developed countries and will identify the most advanced countries in Asea.

Due to this study conducted in Indonesia and its main purpose is to design a character education for the people of Indonesia, the most advanced countries in Asean be a reference in establishing the character of the Indonesian nation. Indonesia on the grounds that the location is in the Asean region, then the most advanced countries in Asean as a reference due consideration of social and cultural conditions.

As a theoretical study, this research is not done in the field (i.e the most advanced countries in Asean). This study aims to find hyphotetic model - pillars of education that can build up motivation (as base) build character behavior. In detail, this study will describe: (1) the pillars that build motivation (basic character), (2) the character of the people in the most advanced countries in Asean.

\section{The Most Developed Country inASEAN}

Based on economic conditions, most of the countries in Southeast Asia are still classified as developing countries, only Singapore which is classified in the developed world. Economy of Southeast Asia is still much dependent on natural resources, with the exception of Singapore. With the establishment of the Southeast Asian free trade area by the ASEAN countries is expected to accelerate economic growth in the region. Singapore as the most globalized country in the world in the 2006 Globalization Index.

"The most advanced country in Southeast Asia is Singapore". Further, it is explained that Singapore has a highly developed economy, especially the electronic sector, petroleum processing, chemicals, mechanical engineering and biomedical sciences. ${ }^{3}$ The success of the economic field makes Singapore as richest country in Southeast Asia. The government has created laws and regulations so that both investors and citizens freely develop.

The characteristics of developed country is that its people have a high quality of welfare. Characteristics of developed country are: Agriculture, including livestock and fisheries for industrialization, sold, exported; Economic activity using modern infrastructure; Developments in science and technology that support industrialization is quick; The average income of the population is high; Education and skills of the population is high enough; Singaporeans have high independence properties; Residents do not depend on nature; The population growth rates are low; Life expectancy is high; The intensity of high mobility.

Singapore is a highly developed market pick. Along with Hong Kong, South Korea and Taiwan, Singapore is one of the four Asian tigers. Singapore has one of the busiest ports in the world and is a center of foreign currency exchange of the fourth largest in the world after London, New York and Tokyo. The World Bank ranks Singapore as the world's top logistics relationships. Singapore's economy is among the ten most open, competitive and innovative in the world. The Singapore government has ensured the welfare of society both in terms of economics, education, and health.

Almost everyone in Singapore can speak more than one language, and many are able to speak three or four languages. Most children raised in bilingual Singapore since childhood, and they also learn other languages as they grow up. Year 2011 Loong promised housing assistance to low-income families. As many as 80 percent of Singapore's residents inhabiting public housing built by the government. The majority of people who inhabit in public house also has an apartment, assurance obtained by the poor Singapore is a testament to the seriousness of the government to the country's economic center of Asia. The government managed to reduce the rate of poverty at the lowest point.

The above description gives an idea and it can be concluded that Singapore is a developed country in Southeast Asia. The description above talks a lot about Singapore's economic conditions. One of the parameters and can even be said to be the main parameter to measure the progress of a country is based on the economic level of the 
population. So that is why the paper justify Singapore as the most developed country in Southeast Asia based on his economy condition.

\section{The Character of Singapore Community}

One of the most interesting aspects of the population of Singapore is a cosmopolitan character. Built by Thomas Stamford Raffles as a trading center since the date of January 29, 1819, the small seaside town of Singapore soon attracted migrants and merchants of the country of China, India, Indonesia, the Malay Peninsula and the Middle East. Thomas S.R looks forward to a better future, he thought that the immigrants came to bring the culture, language, customs, and habits of their own. Hybridization and fusion culture played a role in influencing the cultural diversity which is then formed into various aspects of Singapore society, making the cultural heritage of diverse and dynamic.

In the description of the characteristics of the Singapore community, we look at the history of Singapore first. Characteristics of a society is formed through the journey of life, it may said the history of the life of a society. Singapore is a small island located at the southern tip of the Malay Peninsula in Southeast Asia. His neighbors are in northern and eastern Malaysia and Indonesia in the south, west, and east. Despite its small size, Singapore is a prosperous country. The heart of this country is the capital and the port city of Singapore. Located at the cross roads of international trade, the port of Singapore is one of the busiest in the world.

\subsection{Singapore was Under British Rule in the 1800s and Long Been a Key Post in UK}

The country gained independence in 1963 as a full member of the Federation of Malaysia. Singapore finally leaving the federation in 1965 and became the independent Republic of Singapore. Singapore has a population only slightly upon its establishment as a British trading post in the early 1800s. Currently, Singapore contains a multiethnic society consisting of various nations. ${ }^{4}$ Singapore is also one of the most densely populated countries in the world. Most of Singapore's growth comes from immigration. ${ }^{5}$ Approximately 75 percent of the population is ethnic Chinese. Ethnic Malays, natives of the region, is the second largest ethnic group. They make up about 15 percent of the population. The other major ethnic groups are India and Pakistan. A small number of Europeans, especially from English background, also lived on the island. Each ethnic group customs and Singapore maintained their traditional lifestyle. At the same time, because of the diversity of the population, on the other ethnic tolerance has become a way of life (although the Malay minority sometimes alleged that they were discriminated against by the Chinese community). This tolerance has been driven by the government, which seeks to create a national identity of Singapore from many different nations.

Singapore has four official languages: Malay, Chinese (Mandarin dialect), English and Tamil (a language of southern India) ${ }^{6}$. Malay language is the national language. English is widely used in government and commerce as well as being the main language of instruction in schools.

Religion Singaporeans reflect their origins and covers all the major religions in the world. Chinese people largely embraced Buddhism and Taoism. The Malays and Pakistan are dominated Muslim. Most Indians are Hindu. About 10 percent of the population is Christian. Freedom of worship is guaranteed in the constitution. Singapore upholds education ${ }^{7}$. The literacy rate (percentage of people over the age of 15 who can read and write) in the country of more than 90 percent.

Primary school begins at age 6 and lasts for six years. This rate was followed by secondary education for four or five years, depending on whether the student chooses a short or extended study. The entrance to the high school depending on the results of the test taken after completing the basic level. Students who do not proceed to secondary school academic system can continue to vocational schools, craft, or technique. National University of Singapore was formed in 1980 from the merger of the University of Singapore and Nanyang University.

Singapore is renowned as a country that is clean, neat, and beautiful. How can the state of Singapore earned the nickname clean state? Because the system of government in this country is full of rules "Very tight". Citizens belonging to residents of the submissive. Singaporeans follow very strict rules. Fines for people who make mistakes, even if only a small mistake was arrested by officers or camera, immediately pay a fine of cash in location. Everywhere there is a camera. On the road there is a camera. In the building there is a camera. At the airport there is a camera. Our activities in this country has always followed cameras (CCTV). Except in the toilet and the bedroom, there is no camera. Litter forfeiture. Discard spit carelessly also fined. Dispose of used chewing gum was fined. Nothing forfeiture if we break the rules are very strict in this country. Fines were imposed on those who violate the rules is very high or high. Penalties could be about USD 3-5 million dollars. Singapore is regarded as the most business-friendly country in the world. According the report of The ASEAN Research Landscape "Singapore is the highest rank in doing research". ${ }^{8}$ It was also expalined that Singapore is also in high rank in innovation. The highest rank within ASEAN of diverse citation impact was also Singapore.

\section{Motivation -Platform of Character Behavior}

Motivation is a process that explains the intensity, direction and persistence of an individual to achieve his goal. The three main elements in this definition include the intensity, direction, and persistence.Motivation becomes a force, energy, or power, or a complex situation and readiness within the individual to move towards a certain goal, either consciously or unconsciously. ${ }^{9}$ Motivation of someone can arise and grow through self-intrinsic-extrinsic and of the environment. ${ }^{10}$. Intrinsic motivation is significant with the desire of the self to act in the absence of external

\footnotetext{
${ }^{4}$ https://mobile.facebook.com/pearliewhite/photos/a.200320613335067.49182.170228379677624/1100679013299218/?type=1\&p=0 ${ }^{5}$ https://mobile.facebook.com/pearliewhite/photos/a.200320613335067.49182.170228379677624/1100679013299218/?type $=1 \& \mathrm{p}=0$ ${ }^{6} \mathrm{http}: / /$ go.grolier.com/print?id=a2027100-h\&type=0ta\&product_id=nbk\&text=full\&authcode=nbk

${ }^{7} \mathrm{https}: / /$ mobile.facebook.com/pearliewhite/photos/a.200320613335067.49182.170228379677624/1100679013299218/?type $=1 \& \mathrm{p}=0$

${ }^{8}$ Thomson Reuter Web of Science. Data from The ASEAN Reseach Landscape. November 2015

${ }^{9}$ Ma'mun. 2003

${ }^{10}$ Elliot (2000).; Sue (1999).
} 
stimuli. ${ }^{11}$ Intrinsic motivation will be more profitable and provide constancy in learning. Extrinsic motivation is defined as motivation that comes from outside the individual and can not be controlled by the individual. ${ }^{12} \mathrm{An}$ example that value, prizes and / or awards are used to stimulate the motivation of a person. ${ }^{13}$

\section{Education and Character Building}

The purpose of education is to make the individual to develop and grow into a human being independent, responsible, creative, knowledgeable, healthy, noble and good views of the physical and spiritual aspects. Human morality, which has a very high morality demanded to be formed or constructed.

Indonesian nation not just emit sheen importance of education, but rather how the Indonesian people are able to realize the concept of education by way of guidance, training and empowerment of Indonesian human resources in a sustainable and equitable. This is in line with Law No. 20 of 2003 on National Education System who said that the purpose of education is "... to become a man of faith and fear of God Almighty, noble, healthy, knowledgeable, capable, creative, independent, and become citizens of a democratic and responsible". The essence of the character education in the context of education in Indonesia is the value of education, namely education noble values sourced from Indonesian culture itself, in order to foster the younger generation personality.

Singapore's school system so successful and it is a model for the west. ${ }^{14}$ Singapore's education is strongly committed to capacity building at all levels of the system. Parents, students, teachers, and policy makers share a highly positive but rigorously instrumentalist view of the value of education at the individual level.

Character education is a way of doing everything in the school. It is not one particular program of focus, it is everything we do that influences the kind of human beings students become. Schools have always been interested in three kinds of otcomes: skills, knowledge, and character. A triangle model is used to explain moral development. The left section of the triangle model deals with values. ${ }^{15}$ We recognize that there are core common values, and we are socialized to develop them through (1) role models, such as parents, other adults, peers, and mass media, (2) legends and heroes, people, we look up to, (3) stories and narratives in print, film, TV, or video games, (4) reinforcement. There are cognitive ways we grapple with the moral life, and they include: (1) problem solving processed for helping to make choices, (2) thinking in a way that is clear and straight, not distorted, seeing many possibilities in a situation - shades of gray instead of black and white, (3) the ability to reflect on our experience and to learn from it, (4) the ability to use a framework to make decisions when we genuinely don't know what to do in a hard case. ${ }^{16}$. What does charachet education look like? Character education initiatives can be very modest, like one good teacher doing a few things right, or they can be very elaborate, involving everybody and everything in the some options. Effective character education is not adding a program or set of programs to a school. Rather it is a transformationof the culture and life of the school. ${ }^{17}$ Character education is the deliberate effort to help people understand, care about, and act upon core ethicaal values. ${ }^{18}$ The holistic approach to build character are building a caring community, teach values through the curriculum, class discussions, service learning, explicit instruction in character and values. ${ }^{19}$

\section{Hyphotetic Model - As the Finding of the Research}

There are seven characters that are outstanding in Singapore society, they are: (1) Emotionless , (2) Discipline, (3) Respect to others, (4) Like cleanliness, (5) Resistant in working, (6) Appreciate the work of others , and (7) Good in service and communication (business).

It can be identified that the pillars of education that are able to build the characters, the education that are(1) capable of building human character, (2) able to build a creative man, (3) able to construct a human who has the work ethic, (4) humans are capable of building completed work, (5) able to build a human who has the motivation, (6) was able to build a human being capable of appreciate the time, (7) were able to build a human who "lack of respect" yourself, (8) were able to build human who are good at looking for opportunities, (9) were able to build a clever man to take advantage of opportunities, (10) building a man who are clevet to thank, (11) building a human being capable of collaborating with others, (12) building capable of being appreciated work ethic / reality of on ethnic, and (13) were able to build humans to think objectively.

Before appearing of characters, of course there is a bridge that is relevant for character appearance. The bridge is called a motivation. So in this case, the aim of education actually build the motivation. Motivation is such like spirit that can be manifested in to characters. The findings of research here is an hypothetic concept. It is needed further empirical research to validate the model that was arleady found. In order the other or next research will be trustable, it is suggester to do quantitative research to analyse factorial model. 


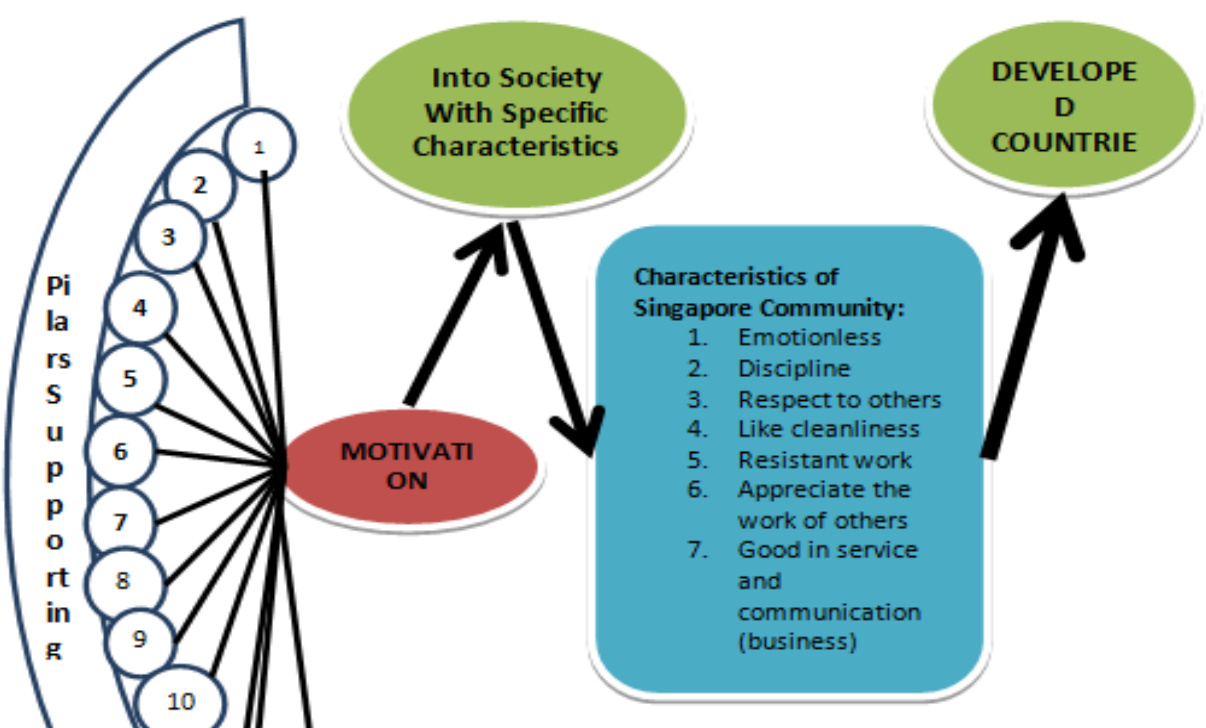

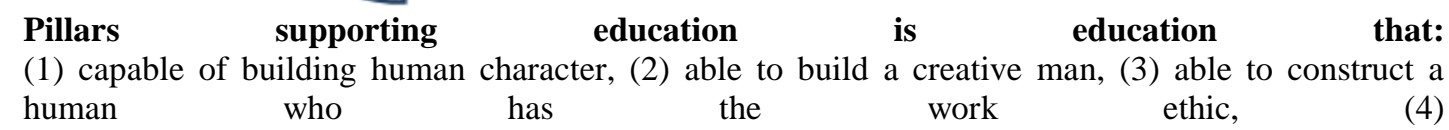

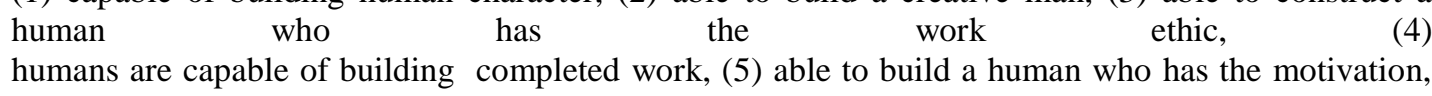
(6) was able to build a human being capable of appreciate the time, (7) were able to build a human who "lack of respect" yourself, (8) were able to build human who are good at looking for opportunities, (9) were able to build a clever manto take advantage of opportunities, (10) building man who are clever to thank, (11) building a human being capable of collaborating with others, (12) building capable of being appreciated work ethic / reality of on ethnic, (13) were able to build humans to think objectively.

\section{Conclusion}

1. The most developed countries in ASEAN is Singapore.

2. The ccategorization of most developed countries is based on economic, social, management, technology, knowledge and education aspects.

3. There are seven kinds of characters which stand out in Singapore namely emotionless society, discipline, respect each other one, like cleanliness, resistant in working, appreciate other people's work, good in service and communication.

4. There are thirteen types of capabilities are assumed to be able to build character motivation.

5. Thirteen kinds of these capabilities in this study are considered as the pillars of education.

6. It is needed for the research determines what kind of education that can be used as a platform to build the pillar.

7. It is needed research to determine the correlation of each pillar of education to each character.

8. Further research is needed for measuring the contribution of each pillar toeach character.

9. The results of this study, associated with the character in the most developed / advanced country in Indonesia (see Singapore) can be a reflection of the Indonesian nation. Such as whether the character of the Indonesian nation?

10. Research about on how education happened in the most advanced countries in Asean (see Singapore) urged to do.

\section{References}

David, H., 2014. Why Singapore's school system so succesful, and is it a model for the West? . Available from conversation.com. Elkind, D.H. and S. Freedy, 2004. How to do character education. Available from Goodcharacter.com [Accessed October 20, 2015].

Elliot, 2000. Dalam artikel pengertian motivasi Menurut Para Ahli. Available from www.pengertianahli.com/2013/09/pengertian-motivasimenurut-paraahli [Accessed October 20, 2015].

Sue, H., 1999. Dalam artikel pengertian motivasi menurut para ahli. Available from www.pengertianahli.com/2013/09/pengertian-motivasimenurut-paraahli [Accessed October 20, 2015].

Tommy, S., 2013. Negaraterkaya di Asia Tenggara. Available from http://tommysyatriadi.blogspot.com/2013/02/negara-terkaya-di-asitenggara.html [Accessed 23 Pebruari 2013].

\section{Bibliography}

Assignment, n.d. Hubungan antara ekonomi dengan Kehidupan sosial budaya. Posted by My College. Available from http://giovandolite.blogspot.com/2013/03/hubungan-antara-ekonomi-dengan.html.

Djohar, 2015. Ekologi Pendidikan. Deskripsi HKI

Djohar and Istiningsih, 2013. Phylosophy of character education. Proceeding International Seminar. PGMI UIN SuKa.

http://opinikuvsopinimu.wordpress.com/2013/20/top-10-negqrq-mqju-dan-makmur/, n.d. Top 10 Negara MajudanMakmur. [Accessed 22 April 2013].

Istiningsih \& Djohar. 2015. Ekologi Pendidikan. Deskripsi HKI

Kompas, 2013. Mendikbud: Kurikulum 2013 lahirkan generasi berpikir obyektif. Available from http://www.matriksweb.com/2014/08/mendikbud-kurikulum-2013-lahirkan.html [Accessed October 20. 2015]. 
Ralph, S., 2015. What do we need to do to get schools to embrace character education? Available from (/auth/logon?sign-in=1) register (/auth/logon?sign-up=1) [Accessed November 20, 2015].

Raraslarasa, 2012. Ciri-ciri Negara majudan berkembang. Available from http://raraslarasa12.wordpress.com/tugas-tugas/data-dataips/geografi/ciri-ciri-negara-maju-dan-berkembang/.

RellyKomaruzaman, n.d. Asia Tenggara. Available from http://id.m.wikipedia.org/wiki/Asia_Tenggara [Accessed November 2nd, 2014].

Retno, 2012. Hubungan antara pendidikan dan pembentukan Karakter Bangsa. Available from http://drdjateng.org/?p=238 [Accessed October $19,2015]$.

Steve, J., n.d. Teaching values in school: An interview with Steve Johnson. Santa Clara University. Available from www.scu.edu/ethics/publications/iie/v13ni/interview.html [Accessed November 20, 2015].

Thomsom, R., 2015. The ASEAN research landscape. Source: ASEAN.

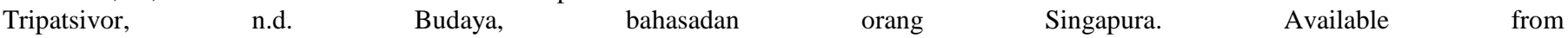
http://www.yoursingapore.com/content/traveller/id/browse/aboutsingapore/people-culture.html. 